\title{
Intervenção em município
}

1. Parecer de Josaphat Marinho, professor catedrático de Direito Constitucional da Universidade Federal da Bahia e professor da Universidade de. Brasília.
Sumário - Intervenção em Município. Atos de corrupção apurados por Tribunal de Contas. Autonomia local e intervenção. Renúncia de Prefeito sob investigação. Assunção de Vice-Prefeito. Legitimação do interventor. Poderes expressos e implícitos. Eficácia e amplitude da intervenção1.

\section{Consulta}

1. O Tribunal de Contas do Estado da Paraíba considerou comprovada, em processo regular, "a prática de continuada corrupção pelo Prefeito Municipal de Taperoá, ... desde o início de sua gestão". Diante disso e do que dispõem o art. $15, \S 3^{\circ}$, letra e, da Constituição da República e o art. 113, IV , da Constituição do Estado, encaminhou o processo ao Governador do Estado, para o fim de intervenção no Município.

É o que consta da Resolução n. 21/80, seguida da de n. 22/80, em que o Tribunal propôs a instauração de "processo criminal" contra o Prefeito, "pelos fatos delituosos arrolados".

Esclarece-se que na apreciação da "auditoria procedida na Prefeitura Municipal de Taperoá", abrangente de "janeiro de 1977 a março de 1980", o voto do Relator assinala ter sido verificado

"cabalmente o verdadeiro descalabro administrativo que caracterizou a condução dos negócios públicos naquele Município, no período acima compreendido, com destaque para ausência de documentação comprobatória de despesas, existência de recibos sem assinatura dos favorecidos, duplicidade de pagamento, ausência de notas fiscais em pagamento de materiais e serviços de elevado custo, além de gastos excessivos na realização de obras públicas, tudo totalizando o montante de Cr\$3.800.827,99 (três milhões, oitocentos mil, oitocentos e vinte e sete cruzeiros e noventa e nove centavos), representativo 
dos prejuízos causados ao Município de Taperoá pela atual administração..."

2. O Governador do Estado," no uso das atribuições que the confere $o$ art. 60 , inciso X, combinado com o art. 113, inciso IV e seu $\S$ $1^{\circ}$. letra $a$, da Constituição do Estado", e à vista do que foi apurado e sugerido pelo Tribunal de Contas, expediu o Decreto n: 8.619, de 21, publicado a 22 de agosto de 1980, declarando:

a) "o Município de Taperoá sob intervenção do Estado durante o prazo de cento e oitenta dias, limitada a medida ao âmbito do Poder Executivo" (art. 1\%);

b) "afastado do cargo o Prefeito..., ou seu substituto, que findo o prazo da intervenção, reverterá às funções, se não houver impedimento legal" (art. 1\%);

c) "nomeado Interventor o Sr. Bel. José de Assis Queiroz, que substituirá o Prefeito e administrará o Município durante o período da intervenção, visando a restabelecer a normalidade e a moralidade administrativas" (art. 2.);

d) "obrigado o Interventor a prestar contas de seus atos ao Governador e de sua administração financeira ao Tribunal de Contas do Estado" (art. 2. , parágrafo único);

e) "em vigor" o ato "na data de sua publicação e é "submetido à "apreciação da Assembléia Legislativa" (art. 3.).

3. Ocorreu, porém, a 20 de agosto, a renúncia do Prefeito, sob a alegação de que o fazia "para evitar" que seus "inimigos" continuassem "a tumultuar a vida administrativa", segundo ofício endereçado ao Presidente da Câmara Municipal.

A 22 de agosto, às 16 horas, em sessão extraordinária da Câmara Municipal, foi declarado vago o cargo de Prefeito, e nele empossado, em seguida, o Vice-Prefeito, conforme ata lavrada.

Acentua-se que o Vice-Prefeito foi investido no cargo de Prefeito quando já publicado no Diário Oficial do Estado o decreto de intervenção.

Não obstante, a argüindo que seu mandato foi arbitrariamente cassado, impetrou mandado de segurança, pretendendo continuar no exercício das funções de Prefeito. Obteve medida liminar, mas a segurança lhe foi indeferida pelo Tribunal de Justiça do Estado.

4. Em face do exposto, e pendente de julgamento recurso extraordinário, o governo do Estado da Paraíba consulta:

a) a intervenção decretada é válida e eficaz?

b) a posse do Vice-Prefeito no cargo de Prefeito, em decorrência da renúncia do titular, prejudica a intervenção?

\section{Parecer}

5. Em trabalho escrito para a VI Conferência Nacional da Ordem dos Advogados do Brasil, observamos que, "no contexto do regime 
federativo, o processo de transformação repercutiu e continua a projetar-se com intensidade. De modo geral, modificam-se os caracteres clássicos do regime, em sua essência ou na extensão adquirida. As constituições ou as práticas políticas e administrativas inserem novos elementos no mecanismo da federação. As inovações resultam em multiplicidade tal de formas de organização e de procedimento que se generalizou a idéia da existência de federações, e não de federação". Ressalvamos, contudo, que, apesar das mudanças, "a federação implica uma distribuição de funções legislativas, executivas e judiciárias entre entidades constitucionalmente criadas e com poderes e recursos específicos. É, por seu caráter, um sistema de atividade descentralizada, conquanto coordenada, e disciplinada de forma incontrastável pela Constituição Federal. Demais, a partilha de competências e recursos abrange comumente três coletividades, pois alcança os municípios, além da União e dos Estados-membros" (Problemas Atuais do Federalismo, in Anais da VI Conferência Nacional da Ordem dos Advogados do Brasil, 1976, pág. 393).

6. Se a Carta vigente no Brasil não é modelo de ordem federativa, de qualquer sorte a proclama instituída. Logo, toda interpretação dela há de ser fundada nos pressupostos do regime, entre os quais se salienta o de autonomia das entidades contempladas no texto. E a Carta assegura, em princípio, a autonomia municipal, pela eleição direta de Prefeito, Vice-Prefeito e Vereadores, assim como por administração própria, no que respeite ao peculiar interesse das comunas (art. 15, lell).

Em conseqüência da regra estabelecida, é evidente que a autonomia somente pode ser cerceada nos casos previstos na Constituição Federal e segundo procedimentos legais adequados.

7. A Carta Política em vigor, reproduzindo instituto conhecido e permitindo, apenas, que seja regulado "na Constituição do Estado", prevê limitativamente a intervenção nos Municípios, pois enumera as hipóteses, inclusive a de prática, na administração local, de "atos subversivos ou de corrupção" (§3. e alínea e, do art. 15).

Essa cláusula não destoa, em essência, da organização federativa. Deve ser escrupulosamente regulada e aplicada, para que divergências meramente partidárias ou circunstâncias estranhas à administração não sirvam de pretexto à perseguição política e ao estrangulamento da autonomia municipal. Circunscrita a medida ao objetivo constitucional, que lhe confere licitude, situa-se no campo de disciplina do mecanismo federativo, notadamente quanto a atos de corrupção. Em verdade, a estrutura federativa pressupõe a coordenação de atividades governamentais entre níveis distintos e delimitados de poder, a fim de que se assegure a ordem político-administrativa, dentro dos fins constitucionalmente traçados.

"Comme toutes les formes de gouvernement constitutionnel, les régimes fédéraux reposent sur le postulat que l'exercice de I'autorité publique devrait, dans les conditions normales, être l'objet de certaines restrictions legales" (Robert R. Bowie et Carl J. Friedrich, Études sur le Fédéralisme, 2. Partie, Lib. Gén. de Droit et de Jurisp., Paris, 1962, pág. 439). 
Às vezes, como ponderam os publicistas citados, as restrições legais não se revelam eficazes. Impõem-se, então, medidas excepcionais, para restabelecimento da normalidade institucional. As formas de intervenção refletidas no direito comparado, como providências adotadas nos regimes federativos, são dessa índole e têm esse objetivo superior. Durand divisou e definiu o fenômeno, há cinqüenta anos:

"Toutes ces interventions des organes fédéraux dans la vie politique des États-membres sont donc exceptionnelles et ne visent qu'à imposer à ces collectivités le respect des principes constitutionnels posés valablement, vis-à-vis d'elles, par la constitution fédéral. La non-intervention reste la règle, au moins en théorie" (Ch. Durand, Les Etats Fédéraux, Rec. Sirey, 1930, pág. 154).

8. No plano das relações entre o Estado-membro e os Municípios, a intervenção não tem outra característica. No Brasil, especialmente, assim há de ser entendida, quer porque prevista, como exceção, na Constituição Federal, quer porque nesta, também, os Municípios estão arrolados como unidades políticas autônomas. Se Pontes de Miranda acentua que "a intervenção pelo Estado-membro é inconfundível com a intervenção federal no Estado-membro", não o faz por ver entre as duas diferença de natureza, mas porque a última "pode ser restrita a alguma zona, ou a algum Município ou alguns Municípios" IComentários à Constituição de 1967, com a Emenda n. I, de 1969, RT, T. II, 1970, pág. 353). Ao que decorre da Constituicãa Federal, porém, sobretudo pelo caráter dos motivos ou casos enunciados - impontualidade no pagamento de empréstimo garantido pelo Estado, ou da dívida fundada; falta de prestação de contas devidas; atos subversivos ou de corrupção, na administração; inaplicação, no ensino primário, em cada ano, do mínimo de vinte por cento da recéta tributária, e inobservância de princípios indicados na Constituição estadual ou desrespeito à execução de lei ou ordem ou decisão judiciária (art. 15, 3.) - a intervenção pelo Estado-membro parece que alcança sempre todo o Município, embora não atinja invariavelmente o funcionamento da Câmara de Vereadores, nem, mesmo, a permanência do Prefeito. Ainda na hipótese de desacato a princípios constitucionais estaduais e à execução de lei ou de ordem ou decisão judiciária, em que o decreto do Governador pode limitar-se a suspender o ato impugnado ( $\xi 3^{\circ}, d$, do art. 15$)$, em realidade a medida restritiva da autonomia estende-se a todo o Município, visto que fulmina a autoridade de seus órgãos constituídos.

9. A amplitude potencial da intervenção, entretanto, não anula o princípio eminente da autonomia dos Estados e dos Municípios, que deve ser preservada, quanto possível. Assevera Durand que a base de apreciação do grau de autonomia de uma coletividade pública, essencialmente, não reside no "pouvoir d'auto-organisation", mas no "bloc des autres compétences exclusives appartenant aux organes propres". Eacrescenta:

"Ce n'est pas le pouvoir de construire une machine (l'ensemble des organes propres) et de la faire fonctionner à vide; c'est celui de lui faire produire quelque chose, c'est-à-dire, des pouvoirs et 
des obligations au profit ou à la charge des citoyens dans leurs rapports entre eux ou avec les services publics" (Ob. e ed. cits., pág. 180).

Exige cautela o pensamento limitativo da importância do poder de auto-organização, sobretudo num estágio da história em que predomina a tendência ao abuso das outorgas recebidas, inclusive para usurpar a competência de outros titulares. Mas é inegável, por igual, a necessidade de valorizar o sentido ético do exercício das tarefas políticas e administrativas, inerente às provisões constitucionais e legais. Nessa linha de política jurídica, que não pode faltar às construções legislativas, a autonomia na federação não é só nem preponderantemente criadora de privilégios e faculdades em favor dos governantes, antes geradora, como assinalado na monografia valiosa, de "poderes e obrigações em proveito ou a encargo dos cidadãos, nas relações entre si ou com os serviços públicos".

Sob essa conceituação irrecusável, a autonomia no quadro federativo impõe ao detentor do mandato político, na função executiva, zelo permanente pela coisa pública, respeito ao interesse coletivo. Se o princípio do governo próprio se desnatura, servindo a procedimento irregular, a intervenção é remédio saneador, de modo que se restaure a regularidade da vida política e administrativa.

Dando-lhe, precisamente, a feição de salvaguarda dos "superiores interesses da Administração e dos administrados", remata o Professor Hely Lopes Meirelles:

"Com as cautelas estabelecidas pela Constituição e com a prudência dos Governadores na utilização desse instrumento de controle das atividades comunais, a intervenção estadual não desfigura o nosso regime municipal, nem descaracteriza as franquias dos governos locais, que devem ser autônomos, mas sujeitos a responsabilizações e sanções pelos desmandos administrativos que cometerem" (Direito Municipal Brasileiro, $3^{\text {a }}$ ed. refundida, RT, 1977, págs. 121-122).

10. A Constituição da Paraíba, guardando fidelidade à Federal, enumera os casos de intervenção no Município (art. 113), inclusive quando

"forem praticados, na administração municipal, atos subversivos ou de corrupção" (IV).

O $1^{\circ}$. do art. 113 regula a forma e a prática da intervenção, prevendo, expressamente:

a) a emissão do decreto, se "comprovado o fato ou a conduta", a que se refere a Constituição, e o dever de submetê-lo o Governador, "dentro de cinco dias, à apreciação da Assembléia Legislativa";

b) a designação de interventor, a determinação do prazo da intervenção e "os limites da medida";

c) a substituição do prefeito pelo interventor, que "administrará - Município durante o período da intervenção, visando a restabelecer a normalidade"; 
d) prestação de contas pelo interventor: "dos seus atos ao Governador e de sua administração financeira ao Tribunal de Contas do Estado";

e) a expedição do decreto e comunicação ao Presidente do Tribunal de Justiça, com "os efeitos da medida", quando se tratar de inobservância de princípios da Constituição estadual "aplicáveis aos Municípios, ou de inexecução de lei, de ordem ou decisão judiciária.

Demais, o § 2. do mencionado art. 113 prescreve, claramente: "Cessados os motivos da intervenção, as autoridades municipais afastadas de suas funções, salvo impedimento legal, a elas reverterão, quando for o caso, sem prejuízo da apuração administrativa, civil ou criminal, decorrente dos seus atos".

Assim, nos limites do Pacto Federal, a Constituição do Estado dispôs de modo a preservar o patrimônio público, o interesse da coletividade, ou seja, a ordem política e administrativa, sem desprezo ao direito das autoridades tidas como responsáveis. Tanto que nela se declara que a finalidade da intervenção é "restabelecer a normalidade" e se assegura o retorno das "autoridades municipais afastadas", "quando for o caso".

Se o restabelecimento da normalidade, que corresponde à restauração da ordem, implica pesquisas diversas e providências coercitivas, ou suspensivas de funções, nisso não há ilegitimidade, desde que restrito o procedimento interventivo às raias constitucionais.

Vale recordar, na lição de Rui, que

"... a ordem, na sua inteireza, consiste, antes de mais nada, na moralidade, no direito, na lei, de cuja observância promana, como derivação natural e imediata, a ordem material" (Comentários à Constituição Federal Brasileira, Col. e Ord. por Homero Pires, Liv. Acadêmica, 1932, 1․ vol., pág. 160).

11. No caso determinante da consulta - cujos textos e documentos referidos examinamos - , o Governador do Estado procedeu com as cautelas da Constituição.

Há que notar, primeiramente, não ter sido decretada a intervenção de ofício, mas por provocação do Tribunal de Contas, em decorrência de Auditoria, no julgamento da qual esse Órgão considerou comprovado "verdadeiro descalabro administrativo", com prejuízo para o Município de Taperoá do vulto de três milhões e oitocentos mil cruzeiros, tudo resultante de "continuada corrupção".

Conseqüentemente, não há que presumir ação política, por motivo menos digno, antes intervenção especificamente fundamentada, segundo irregularidades e desvios apurados pelo Tribunal competente, envolvendo o procedimento e a responsabilidade do Prefeito e de sua administração, "de janeiro de 1977 a março de 1980".

Além disso, o decreto, que a Assembléia Legislativa aprovou pela Resolução n. 363, de 28 de agosto de 1980, fixou em 180 dias o prazo da intervenção (art. 1\%), nomeou Interventor para administrar o 
Município, "visando a restabelecer a normalidade e a moralidade administrativas" (art. 2.).

Corretamente, o decreto declara "afastado do cargo o Prefeito..., ou seu substituto", assegurando, ao fim da intervenção, o retorno ao cargo, "se não houver impedimento legal" (art. 1.). Por essa forma, garantiu, a um tempo, a eficácia da intervenção e o direito ao exercício do cargo de quem não resultasse legalmente impedido.

12. O afastamento do Prefeito, a par de previsto na Constituição estadual (art. $113, \S 11^{\circ}, \mathrm{c}$ ), é medida natural, destinada a assegurar, na generalidade dos casos, o êxito da intervenção.

No regime de 1891, a Constituição silenciava sobre a designação de interventor. A prática supriu o texto. Como informa Pedro Calmon,

"Tiramos à experiência constitucional argentina a figura do interventor.

Implícita no instituto da intervenção, decorrendo desta, como a personificação do Poder competente para corrigir a vida estadual perturbada, a política e a jurisprudência consagraram aquela entidade de direito federal" (Intervenção Federal, Liv. Edit. Freitas Bastos, 1936, pág. 118).

Hoje, prevista a figura do interventor, no domínio federal (Const. Fed., art. 12) e nos Estados (Consts.: Amazonas, art. 177, § 2.; Ceará, art. 24, § 1․, III; Minas Gerais, art. 187, parágrafo único; Paraíba, art. $113, \S 1$. , b, c ed; R.G. Sul, art. 151; S. Paulo, art. 106, § $1 \stackrel{\circ}{ }, n^{\circ} .2,3$ e 4 ; etc. I, a ilegitimidade de sua designação não pode ser argüida em princípio, mas em situação concreta, à luz de motivos constitucionalmente ponderosos.

13. A renúncia do Prefeito, cuja responsabilidade se quer apurar, e a assunção do cargo pelo Vice-Prefeito não representam fatos que obstem os efeitos da intervenção e impeçam a ação do interventor.

Em primeiro lugar, atente-se em que, se tal fosse admitido, a astúcia e a malícia, a serviço de propósitos pessoais, obstruiriam a execução de medida política excepcional, adotada para defesa do interesse público e coletivo.

Depois, a simples renúncia do Prefeito não elimina as causas da intervenção, nem anula os objetivos desta medida. Somente a apuração dos fatos definirá e excluirá responsabilidades e esgotará a finalidade da intervenção. Além da responsabilidade penal, cujo reconhecimento conclusivo cabe ao Poder Judiciário, há verificações, providências e atos administrativos diversos, que se desdobram na execução da intervenção. Essas medidas é que conduzem ao restabelecimento da normalidade da vida municipal.

Daí Aurelino Leal ter observado a respeito da intervenção nos Estados, sob o sistema de 1891, que "o delegado do governo federal deve praticar atos de conservação", que se estendem do "expediente da administração" e das providências de "polícia e segurança 
pública" até a "liquidação de dívidas" e o "pagamento de empréstimos externos" (Teoria e Prática da Constituição Federal Brasileira, Rio de Janeiro, F. Briguiet e Cia. Editores, 1925. pág. 94). cluiu:

Por isso, também, no regime atual, Pontes de Miranda con-

"O Poder Executivo, na intervenção, no Estado de sítio e noutras medidas, não tem simples função de poder executivo, nem de alta polícia; exerce poder de decretar ou de executar medida de proteção da estrutura do Estado, da Constituição" (Comentários à Constituição de 1967, com a Em. n. I, de 1969, T. II, 1970, 2. ed., RT. pág. 192).

É óbvio, portanto, que as funcões do interventor, como executor da providência extraordinária, não podem ser transferidas a órgão da entidade sob intervenção, sem risco de ineficácia.

14. Dentro de limitações compreensíveis, o mesmo quadro se desenha no processo de intervenção dos Estados nos Municípios. Como naquela intervenção maior, nesta se busca, também, proteger a estrutura do Município e a Constituição do Estado, restaurando o funcionamento regular do poder local - o que pressupõe, de regra, seja afastado o Prefeito.

15. Por iguais razões, a assunção do Vice-Prefeito - e no caso quando já publicado o decreto da intervenção - não tem força para impedir os efeitos da medida corretiva. Mesmo que o decreto não estendesse o afastamento do cargo ao "substituto" do Prefeito, como estendeu, essa conseqüência seria logicamente abrangente dele, ou de quem estivesse em exercício, pela natureza da intervenção.

Não importando o afastamento, necessariamente, em perda do cargo, como aliás dito no decreto, não ocorre violação de direito. Não se trata de punição, mas de medida preventiva. O titular retornará, se for o caso.

Mas a presença e a ação do Interventor na Prefeitura são indispensáveis à execução da medida, para que se restaure a normalidade política e administrativa. À conquista desse objetivo superior não pode ser obstáculo o interesse pessoal de ninguém.

"Admitida a intervenção - argüiu Rui, quando a entidade do interventor ainda não estava delineada na Constituição - o que se quer saber é que meios poderá ela requerer para ser eficaz. A eficácia desses meios não tem limites senão na sua legitimidade, e esta só cessará de existir quando o meio adotado for de encontro a algum outro direito ou poder estabelecido na Constituição" (Ob., ed. evol. cits., pág. 218).

A intranqüila e precipitada sucessão na Prefeitura de Taperoá mostra que não há direito oponível à intervenção e a seus efeitos.

A medida excepcional, porém, requer, sem excesso, meios amplose seguros, que propiciem a correção das anomalias. 
2. José Guilherme Villela, advogado em Brasília.
É por isso que prevalece o entendimento sustentado, como neste comentário de José Afonso da Silva:

"O interventor substituirá o Prefeito e administrará o Município durante o período da intervenção, visando a restabelecer a normalidade, prestando contas de seus atos ao Governador, e, de sua administração financeira, ao Tribunal de Contas do Estado, bem como respondendo pelos excessos que cometer" (Curso de Direito Constitucional Positivo, 1976, RT. Vol. I, pág. 182).

Titular de mandato local, que sucede ao investigado por artifício manifesto, não tem condições para repor o Município no leito da legalidade e da ordem administrativa, nem é portador de direito oponível aos efeitos da intervenção.

Na teoria dos poderes expressos e implícitos, que herdamos ao Direito americano, é compreensão soberana que "quem quer os fins, quer os meios", ou seja, "conferida uma atribuição, nela se consideram envolvidos todos os meios necessários para a sua execução regular" (Rui. Ob., ed. evol. cits., págs. 210 e 217).

É o caso: outorgado ao Estado-membro o poder de intervenção no Município, nessa franquia se incluem todos os meios e instrumentos indispensáveis à execução plena da medida. Quando ocorrem, como no caso, fatos graves e determinantes de amplas providências corretivas, o afastamento da autoridade local e a presença do interventor são providências indissociáveis da eficácia da intervenção.

\section{Resposta às questões}

16. Diante dessas razões expostas, respondemos conjuntamente as duas questões suscitadas na consulta: É válida e eficaz a intervenção decretada, não a prejudicando, nem lhe reduzindo a amplitude, a renúncia do Prefeito sob investigação, nem a ascensão do VicePrefeito ao cargo declarado vago pela Câmara de Vereadores.

Salvo melhor juizo.

$$
\text { Brasília, 8de junho de } 1981 .
$$

Este parecer foi oferecido no recurso extraordinário número 94.252-1 Paraiba perante o Supremo Tribunal Federal. O advogado da mesma parte José Guilherme Villela2 nele, igualmente submeteuo seguinte Memorial:

Intervenção do Estado da Paraíba no Município de Taperoá, por motivo de corrupção administrativa.

- Recurso extraordinário inadmissível, por versar sobre normas impertinentes e não prequestionadas.

- A intervenção não é sanção civil ou penal contra o Prefeito corrupto, mas medida de caráter político-constitucional, que visa a restabelecer a normalidade da vida financeira do Município, seriamente afetada pelo descalabro administrativo comprovado por inspeção do Tribunal de Contas do Estado. 
- A renúncia do Prefeito no momento da intervenção foi expediente inócuo para frustrar os efeitos dessa providência regularmente decretada pelo Governador, por provocação do Tribunal de Contas e com aprovação da Assembléia Legislativa.

\section{Súmula dos fatos}

No exercício de sua função de auditoria, verificou o Col. Tribunal de Contas da Paraíba a prática de escabrosa corrupção administrativa no município de Taperoá, em virtude dos graves fatos assim narrados na parte preambular do douto voto do eminente Conselheiro-Relator:

"O relatório da Auditoria de fls. 02 a 08 comprova cabalmente o verdadeiro descalabro administrativo que caracterizou a condução dos negócios públicos naquele Município, no período acima compreendido, com destaque para ausência de documentação comprobatória de despesas, existência de recibos sem assinatura dos favorecidos, duplicidade de pagamento, ausência de notas fiscais em pagamento de materiais e serviços de elevado custo, além de gastos excessivos na realização de obras públicas, tudo totalizando o montante de Cr\$3.800.827,99 (três milhões, oitocentos mil, oitocentos e vinte e sete cruzeiros e noventa e nove centavos), representativo dos pre-juízos causados ao Município de Taperoá pela atual administração do Prefeito José Vilar" (fl. 41).

2. A gravidade dos fatos apurados levou o Col. Tribunal de Contas a baixar, por unanimidade, as Resoluções n.s 21/80 e 22/80, a primeira para sugerir ao Governador a intervenção no referido município (fls. 37/38) e a segunda para recomendar ao Ministério Público a instauração de processo criminal contra o Prefeito José Vilar (fl. 39)

3. Percebendo, de imediato, que não podia condescender com a dilapidação do erário municipal, que assumia proporções alarmantes em relação ao volume dos parcos recursos da comuna, o Governador do Estado decretou a intervenção, de acordo com o Decreto n? 8.619, de $21 / 8 / 80$, publicado no D.O. de $22 / 8 / 80$, que tem o seguin-
te teor:

"O Governador do Estado da Paraíba no uso das atribuições que Ihe confere 0 art. 60 , inciso $X$, combinado com o art. 113, inciso IV seu $\S 1$. , letraa, da Constituição do Estado, e

CONSIDERANDO a prática de atos de corrupção na administração municipal de Taperoá pelo Prefeito José Vilar, apurada e comprovada através de inspeção realizada pelo Tribunal de Contas do Estado, conforme processo n. TC 2933/80 originário daquela Corte de Contas,

\section{DECRETA:}

Art. 1. - Fica o Município de Taperoá sob intervenção do Estado durante o prazo de cento e oitenta dias, limitada a medida ao âmbito do Poder Executivo, sendo, em conseqüência, afastado do cargo o 
Prefeito José Vilar, ou seu substituto, que, findo o prazo da intervenção, reverterá às funções se não houver impedimento legal.

Art. 2. - É nomeado Interventor o Sr. Bel. José de Assis Queiroz, que substituirá o Prefeito e administrará o Município durante o período da intervenção, visando a restabelecer a normalidade e a moralidade administrativas.

Parágrafo único - O Interventor prestará contas de seus atos ao Governador e de sua administração financeira ao Tribunal de Contas do Estado.

Art. $3^{\circ}$ - Este Decreto entrará em vigor na data de sua publicação, revogadas as disposições em contrário, e é submetido, nesta data, à apreciação da Assembléia Legislativa, na forma da Constituição do Estado" (fl. 19).

4. Submetido o decreto de intervenção ao crivo da Assembléia Legislativa, foi o ato aprovado pela Resolução n. 63 , de 28/8/80, publicada no órgão oficial de 29. Vê-se, pois, que concorreram para a intervenção o Tribunal de Contas, o Governador do Estado e a Assembléia Legislativa, o que, por si só, está a evidenciar a seriedade e a necessidade dessa medida extrema, absolutamente indispensável à normalização da administração financeira de Taperoá.

5. Quase como uma confissão, o Prefeito Vilar forneceu o documento de fl. 8, que é um ofício-renúncia datado de $20 / 8 / 80$ e assim redigido:

"Comunico a Vossa Excelência e demais Vereadores que, neste momento, estou renunciando, em caráter irrevogável, ao cargo de Prefeito Constitucional deste Município, e o faço para evitar que os meus inimigos continuem a tumultuar a vida administrativa, sob a minha responsabilidade, impondo, necessariamente, graves e irreparáveis prejuízos ao Povo de minha terra.

Como se sabe, o ato de renúncia é unilateral, pelo que dispensa aprovação, facultando a mim, Prefeito renunciante, transmitir, imediatamente, o cargo ao meu sucessor legal".

6. A data aposta nesse ofício $(20 / 8 / 80)$ só esta atestada pela declaração do Presidente da Câmara - suspeito correligionário do renunciante - , que convocou a Edilidade às pressas e deu posse ao Vice-Prefeito, na presença de apenas três Vereadores, às 16 horas do dia 22/8/80 (fl. 10), quando o decreto de intervenção no município já estava publicado no D.O. do mesmo dia $22 / 8 / 80$ (fl. 19), que circula pela manhã, como o confirma o v. acórdão recorrido (fl. 79).

7. Apesar de tão suspeita investidura no cargo de Prefeito Municipal, sucedendo ao renunciante, o Vice-Prefeito, ora recorrente, ajuizou segurança para invalidar o decreto de intervenção, alegando que tal decreto cassava-lhe o mandato em razão de atos praticados pelo ex-titular da Prefeitura.

8. Depois de conseguir a suspensão dos efeitos da intervenção, em virtude de liminar concedida pelo eminente DesembargadorRelator (fl. 22 v. / 23), o impetrante-recorrente acabou, como se esperava, derrotado no Col. Plenário do Tribunal de Justiça, que lhe denegou a Segurança impetrada. 


\section{Decisão recorrida}

9. A denegação da Segurança decorreu de precisa motivação do v. acórdão plenário de fls. 76/80, do qual o recorrido transcreve o trecho que interessa ao julgamento do recurso extraordinário, verbis:

"Por outro lado ninguém pode ter em dúvida a competência do Governador para decretar intervenção nos municípios e nomear-Ihes interventor, desde que ocorram os pressupostos legais e previstos pela Constituição Federal no seu art. 15, Constituição Estadual art. 113 § 1. e seguintes em harmonia com o art. 105 seus parágrafos e incisos da Lei Orgânica dos Municípios. No caso dos autos, houve uma concorrência uniforme desses requisitos legais.

A renúncia do Prefeito atingido pelo ato governamental de intervenção e que deu acesso ao Vice-Prefeito, não pode prosperar, uma vez que a medida é dirigida claramente ao Executivo Municipal e não simplesmente ao respectivo Prefeito. Se tal não ocorresse, isto é, se o Vice-Prefeito pudesse substituir em tais circunstâncias o Prefeito afastado, nulo e mesmo imprestável ficaria o instituto da intervenção, assegurado pela Carta Magna. Entretanto, a Constituição Estadual e a Lei Orgânica dos Municípios dizem expressamente que, decretada a intervenção no Município, o Prefeito afastado será substituído por um interventor nomeado pelo Governador. Releva destacar ainda que, quando o Vice-Prefeito ora impetrante assumiu o cargo, o Município de Taperoá já estava sob intervenção do Estado e com um interventor nomeado.

Veja-se a respeito o que publica o Diário Oficial do Estado de 22/10/1980 e que circulou pela manhã daquela dia trazendo na íntegra o decreto de intervenção, enquanto que o Vice-Prefeito somente assumiu o cargo de Prefeito às 16 horas naquele dia, o que lhe era defeso fazer, estando como estava o Município sob o regime de intervenção. Claro, que dentro de tais circunstâncias o ato impugnado nenhum gravame causou ao direito subjetivo do impetrante, inocorrendo por isso mesmo, em seu favor direito líquido e certo a ser protegido pelo Mandado de Segurança.

Em nada pode aproveitar ao impetrante o argumento de que a renúncia do titular tornou sem objeto o decreto de intervenção, de volvendo-lhe o direito pleno ao exercício do cargo como seu legítimo sucessor. Isto porque, como se disse, o Município já estava sob o regime jurídico da intervenção quando da sua assunção ao cargo e mesmo que não estivesse, restaria ainda o argumento sustentado que a intervenção se dirige especificamente contra o Executivo Municipal e não exclusivamente contra seu Prefeito" (fls. 78/79).

\section{Recurso extraordinário}

10. Inconformado com a irrespondivel fundamentação do aresto, o vencido interpôs recurso extraordinário (fls. 82/85), alegando, pela letra d, divergência com r. despacho do eminente Presidente Antônio Neder na SS 115 e, pela letra a, ofensa a dispositivos impertinentes e não prequestionados da Constituição Federal, do Código Penal, do Código Eleitoral e do D.L. 201/67. 
Para maior fidelidade, transcreva-se o tópico da petição em que são mencionadas as normas supostamente ofendidas, isto é:

"Assim o faz, por entender que o douto julgado recorrido negou aplicação aos parágrafos $3^{\circ}, 13^{\circ}$ e $21^{\circ}$. do art. 153 da Constituição Federal, bem assim aos arts. 1ㅇ, § 1. e 154, § único da Lei Magna, além de agredir os dispositivos vigentes do Código Eleitoral, lei federal, e negar vigência aos arts. $1^{\circ}, 11^{\circ}$ e e $312^{\circ}$. do Decreto-lei federal 2.848 de 7 de dezembro de 1940, Código Penal em vigor, e ainda ao que dispõe o Decreto-lei 201 de 27 de fevereiro de 1967, como se verá a seguir, nas razões do presente recurso, que pede seja deferido, ex vi legis, pelo que, com a devida vênia, passa a fundamentá-lo" (fl. 82).

11. Sendo óbvio que uma decisão judiciária singular não se presta a confronto para o efeito da letra $d$ e que não foram prequestionados os impertinentes preceitos legais invocados, poderia o recorrido finalizar este memorial. No entanto, por dever de ofício, o patrono do recorrido passa a demonstrar a plena legitimidade e regularidade do ato impugnado pelo recorrente.

\section{Legitimidade e regularidade do decreto de intervenção no municipio}

12. Se, como já se disse, não se pode censurar a motivação do ato de intervenção, não é possivel deixar de reconhecer-lhe também sua plena legitimidade, porquanto, embora a Constituição Federal assegure a autonomia municipal pela administração própria no que concerne ao peculiar interesse do município, previu casos excepcionais, em que a intervenção estadual se justifica (art. $15, \S 3^{\circ}$ ). Vale reproduzir a norma constitucional, da qual ressalta a preocupação do constituinte de 1969 pela boa gestão dos dinheiros públicos, como se depreende do seguinte $\S 3^{\circ}$ :

A intervenção nos Municipios será regulada na Constituição do Estado, somente podendo ocorrer quando:

a) se verificar impontualidade no pagamento de empréstimo garantido pelo Estado; da;

b) deixar de ser paga, por dois anos consecutivos, dívida funda-

c) não forem prestadas contas devidas, na forma da lei;

d) o Tribunal de Justiça do Estado der provimento a representação formulada pelo Chefe do Ministério Público local para assegurar a observância dos princípios indicados na Constituição Estadual, bem como para prover à execução de lei ou de ordem ou decisão judiciária, limitando-se o decreto do Governador a suspender o ato impugnado, se essa medida bastar ao restabelecimento da normalidade;

e) forem praticados, na administração municipal, atos subversivos ou de corrupção; e

f) não tiver havido aplicação, no ensino primário, em cada ano, de vinte por cento, pelo menos, da receita tributária municipal. 
13. Provendo a respeito do problema, a Constituição paraibana, dentro dos limites que lhe foram reservados pelo constituinte federal, assim regulou a matéria:

Art. 113. O Estado somente intervirá no Município quando:

I. verificar impontualidade no pagamento de empréstimo garantido pelo Tesouro estadual; da;

II. deixar de ser paga, por dois anos consecutivos, dívida funda-

III. não forem prestadas contas devidas, na forma da lei;

IV. forem praticados, na administração municipal, atos subversivos ou de corrupção;

V. não tiver havido aplicação, no ensino primário, em cada ano, de vinte por cento, pelo menos, da receita tributária municipal;

VI. o Tribunal de Justiça der provimento à representação formulada pelo Procurador-Geral da Justiça para assegurar a observância dos princípios desta Constituição, aplicáveis aos Municípios, bem como para prover à execução da lei, ordem ou decisão judiciária, limitando-se o decreto do Governador a suspender o ato impugnado, se essa medida bastar ao restabelecimento da normalidade.

§ 1. A intervenção far-se-á por decreto do Governador, observados os seguintes requisitos:

a) comprovado o fato ou a conduta prevista nos itens I a IV, o Governador, de ofício ou mediante representação do interessado, decretará a intervenção e submeterá o decreto, com a respectiva justificação, dentro de cinco dias, à apreciação da Assembléia Legislativa, que será para tal fim convocada, se estiver em recesso;

b) o decreto conterá a designação do interventor, o prazo da intervenção e os limites da medida;

c) o interventor substituirá o prefeito e administrará o Município durante o período da intervenção, visando a restabelecer a normalida-
de;

d) o interventor prestará contas dos seus atos ao Governador e de sua administração financeira ao Tribunal de Contas do Estado;

e) no caso do inciso VI, o Governador expedirá o decreto e comunicará ao Presidente do Tribunal de Justiça os efeitos da medida.

$\S 2^{\circ}$. Cessados os motivos da intervenção, as autoridades municipais afastadas de suas funções, salvo impedimento legal, a elas reverterão, quando for o caso, sem prejuízo da apuração administrativa, civil ou criminal decorrente dos seus atos.

14. A transcrição das normas constitucionais federais e estaduais evidencia, por si só, que o decreto de intervenção seguiu à risca os preceitos aplicáveis, não se tendo praticado qualquer ilegalidade ou abuso de poder, que pudesse dar lugar a mandado de segurança. 
dida tomada pelo Executivo, por provocação do Tribunal de Contas, que resistiu ao controle do Poder Legislativo e do Poder Judiciário da Paraíba.

15. Apesar de considerar evidente a legitimidade e regularidade da intervenção no caso, o recorrido reconhece que o eminente Presidente Antônio Neder, num feito de cognição incompleta porque relacionado com uma suspensão de liminar, assim não o entendeu. O r. despacho de Sua Excelência (fls. 109/116) revela que a circunstância da renúncia do Prefeito faltoso foi decisiva para formar sua convicção no sentido de não se justificar a intervenção decretada, cujos objetivos teriam sido atingidos com a renúncia em causa.

16. D.v., não atentou o eminente Ministro para o fato de não ser objetivo da intervenção apenas afastar o Prefeito, mas também e principalmente normalizar a administração financeira do município. Esse objetivo, a toda evidência, não seria atingido se, em lugar do Prefeito renunciante, ficasse o Vice-Prefeito, eleito pela mesma legenda partidária e plenamente solidário com os atos praticados pelo antecessor, tanto que nenhuma providência tomou em relação à apuração dos fatos criminosos durante os meses em que ficou à frente do Executivo por efeito da liminar.

17. O saneamento das finanças municipais exige a presença de um Interventor estadual, que terá amplo acesso aos livros, papéis e documentos da Prefeitura, com possibilidade de determinar toda a extensão dos prejuízos decorrentes dos 4 anos da administração José Vilar, que, segundo o Tribunal de Contas, ascendem a quase $4 \mathrm{mi}-$ Ihões de cruzeiros, cifra impressionante dentro da parcimônia dos recursos do pequeno município de Taperoá.

18. Por outro lado, as circunstâncias bastante suspeitas da renúncia do Prefeito corrupto e da posse do recorrente estão a assinalar que tudo não passou de um expediente para frustrar o decreto de intervenção e a concretização de seus propósitos saneadores das finanças municipais. Se tal expediente pudesse prosperar, nunca mais seria possível intervir nos municípios, porque sempre um conluio do titular da Prefeitura com seu substituto possibilitaria que o primeiro se afastasse do cargo, mas conservasse sua influência e persistisse na prática da corrupção administrativa.

19. Finalmente, não vem ao caso que o substituto do faltoso não haja praticado as faltas, porque a intervenção é medida políticoconstitucional e não processo de caráter penal, que deva levar em conta a responsabilidade pessoal do delinqüente. O Prefeito renunciante vai responder, no juízo próprio, civil e criminalmente, pelos atos praticados contra o erário de Taperoá, como recomendou também o Tribunal de Contas. Urge, todavia, normalizar a vida administrativa do município profundamente afetada pelo descalabro dos 4 anos da administração José Vilar. Esse superior objetivo, que é do interesse de toda a comuna, só poderá ser alcançado com a intervenção decretada, a qual caberá a um alto funcionário do próprio Tribunal de Contas, inteiramente alheio aos interesses da política partidária, que tantos danos causaram ao município em 4 anos de administração corrupta e leviana. 
3. Acórdão publicado no Diário da Justiça de 7/8/81, ementário número 1.220-2.
20. Em suma, o recorrido confia em que o recurso extraordinário não será conhecido, para prestígio dos poderes estaduais da Paraíba, que agiram com presteza e energia para coibir a corrupção administrativa e viabilizar a punição dos que por ela respondem.

Brasília, 6 de junho de 1981

A questão ficou assim decidida:

Supremo Tribunal Federal da República Federativa do Brasil. Recurso extraordinário número 94.252-1. Recorrente Ministro Manoel de Farias Souza Filho. Recorrido: Estado da Paraíba. Relator: João Leitão de Abreu.

Ementa: Intervenção do Estado no municipio (CF, art. 15, § $3^{\circ}$ ). 1 - Éato político-administrativo, que não importa na imposição de pena ao prefeito. 2 - Atos de corrupção na administração municipal. A renúncia antecipada do prefeito titular e a assunção do cargo pelo vice-prefeito não obstam juridicamente a intervenção. Assiste, por isso, ao governador, o poder juridico de nomear o interventor, como seu delegado, para o fim de restabelecer a ordem na administração. 3 - Improcedência do pedido de segurança ajuizado pelo vice-prefeito. 4 - Recurso extraordinário não conhecido?

\section{Acórdão}

Vistos, relatados e discutidos estes autos, acordam os Ministros da Segunda Turma do Supremo Tribunal Federal, na conformidade com a ata de julgamentos e notas taquigráficas, por unanimidade de votos, em não conhecer do recurso.

\section{Brasília, 9 de junho de 1981.}

\section{Relatório}

O Senhor Ministro Leitão de Abreu: O Chefe do Poder Executivo do Estado da Paraíba expediu, com data de 21 de agosto de 1980 , o Decreto n: 8.619, pelo qual decretou a intervenção no Município de Taperoá. O ato de intervenção está assim redigido: O Governador do Estado da Paraíba no uso das atribuições que
Ihe confere o art. 60 , inciso X, combinado com o art. 113, inciso IV e seu $§ 1$ ? , letra "a", da Constituição do Estado e,

CONSIDERANDO a prática de atos de corrupção na administração municipal de Taperoá pelo Prefeito José Vilar, apurada e comprovada através de inspeção realizada pelo Tribunal de Contas do Estado, conforme processo n. TC 2.933/80 originário daquela Corte de Contas,

\section{DECRETA:}

Art. 1. - Fica o Município de Taperoá sob intervenção do Estado durante o prazo de cento e oitenta dias, limitada a medida ao âmbito do Poder Executivo, sendo, em conseqüência, afastado do cargo o 
Prefeito José Vilar, ou seu substituto, que, findo o prazo da intervenção, reverterá às funções se não houver impedimento legal.

Art. 2. - É nomeado Interventor o Sr. Bel. José de Assis Queiroz, que substituirá o Prefeito e administrará o Município durante o período da intervenção, visando a restabelecer a normalidade e a moralidade administrativas.

Páragrafo único - O Interventor prestará conta de seus atos ao Governador e de sua administração financeira ao Tribunal de Contas do Estado.

Art. 3. - Este Decreto entrará em vigor na data de sua publicação, revogadas as disposições em contrário, e é submetido, nesta data, à apreciação da Assembléia Legislativa, na forma da Constituição do Estado." (fl. 19).

Contra esse ato impetrou mandado de segurança Manoel de Farias Souza Filho, Vice-Prefeito do Município. Diz, na impetração, que, na qualidade de Vice-Prefeito, devidamente diplomado, foi empossado no cargo de Prefeito de Taperoá, no dia 22 do mês de agosto, diante da renúncia do Prefeito, verificada no dia 20 do referido mês. Diz mais que, não obstante isso, o Senhor Governador do Estado, por decreto de intervenção, publicado no "Diário Oficial" do mesmo dia 22, além de afastar do cargo o Prefeito, que já renunciara, afastou também o seu substituto, isto é, o Vice-Prefeito, que, réu sem culpa, viu cassados, pelo Chefe do Poder Executivo, os seus direitos políticos, ou, mais precisamente, o direito que lhe assistia de exercer o mandato eletivo de que era titular. Alega, na petição de segurança, que o Senhor Governador do Estado infringiu o disposto no art. 15, I, e 153, §3.․, da Constituição Federal, bem como o art. 109 da Constituição Estadual, achando-se configurado, na hipótese, abuso de poder.

O Desembargador-relator, deferindo o pedido de liminar, suspendeu os efeitos do ato impugnado, isto é, do Decreto Municipal n? 8.619, de 21/8/80, tendo o então Presidente do Supremo Tribunal, Ministro Antônio Neder, negado a cassação da liminar.

Prestadas as informações pela autoridade apontada como coatora e ouvida a Procuradoria-Geral da Justiça, o Tribunal de Justiça denegou a segurança, em acórdão do teor seguinte:

"

1. Alegando violação no seu direito, o cidadão Manoel de Farias Souza Filho impetrou Mandado de Segurança contra ato do Exmo. Sr. Governador do Estado que decretou intervenção no município de Taperoá, do qual o impetrante é Vice-Prefeito com exercício no cargo de Prefeito Municipal, face à renúnica do respectivo titular, Sr. José Vilar. Alega o requerente que o ato do Exmo. Governador infringiu dispositivo da Constituição Federal, da Constituição Estadual e da Lei Eleitoral, considerando letra morta o diploma de Vice-Prefeito que lhe foi outorgado pela Justiça Eleitoral.

Sustenta que o decreto de intervenção no município de Taperoá não poderia atingir o suplicante, uma vez que o mesmo nunca esteve 
no exercício do cargo de Prefeito, somente assumindo agora no dia 22 de agosto, não podendo figurar como envolvido ou implicado nos alegados atos de corrupção administrativa apontados pelo Tribunal de Contas do Estado.

Alega que está perfeitamente configurado o abuso do poder por parte do Governador do Estado, o qual agiu por mero arbítrio. Por fim sustentando violação do seu direito líquido e certo, o requerente pleiteou a concessão da liminar para a suspensão do ato impugnado.

Pelo Relator da matéria, Des. Francisco Espínola, foi concedida a liminar pleiteada e decretada a suspensão dos efeitos do ato impugnado até o julgamento final da causa. Com a suspensão do ato impugnado, ou seja, decreto n: 8.619 , de 21 de agosto de 1980 , fazendo permanecer no cargo de Prefeito o ora impetrante, Manoel de Farias Souza Filho, ordenando o Relator no mesmo despacho a notificação da autoridade apontada como coatora, para prestar as informações necessárias.

A autoridade apontada como coatora prestou as suas informações, alegando que o impetrante foi afastado do exercício do cargo de Prefeito do município de Taperoá por força do decreto de intervenção publicado no Diário Oficial de 22 de setembro próximo passado com apoio do artigo 15, § $3^{\circ}$, letra e da Constituição Federal, combinado com o art. 113, inciso IV, letra a e seu § 3. da Constituição Estadual. Alude, ainda, o Governador que a medida de intervenção teve por fim restaurar a probidade administrativa atingida por irregularidade praticada na Prefeitura daquele Município e apuradas em processo de Auditoria levado a efeito pelo Tribunal de Contas do Estado, através do qual ficou constatada a prática reiterada de ato de corrupção. Sustenta ainda, que ficou amplamente demonstrado na mensagem enviada à Assembléia Legislativa do Estado a medida aplicada através do decreto 8.619, com rigorosa observância dos pressupostos legais que descaracteriza o chamado "abuso do poder" sustentado pelo impetrante. É relevante considerar que o direito subjetivo ao exercício do mandato eletivo, no caso em espécie, é direito que já nasce mutilado, ante a possibilidade de incidência da norma constitucional.

Por fim pede Sua Excelência, o Governador do Estado, que seja admitida a legalidade do ato intervencionista, que assegura a ordem constitucional que repele a prática de atos de corrupção administrativa, impondo-se assim o indeferimento da segurança requerida pela sua manifesta impertinência e descabimento.

Emitindo seu parecer sobre o pedido, a douta Procuradoria opinou em preliminar pelo não conhecimento do pedido, face à publicação e circulação do decreto antecederem a posse do impetrante. No mérito todavia, Sua Excelência entendia devesse a medida ser concedida por entender que o ato governamental fere direito líquido e certo do impetrante a ser reparado através do Mandado de Segurança.

2. A matéria foi amplamente debatida sob todos os ângulos em alguns aspectos, extrapolando o âmbito a que deve se limitar discussão de ato político-administrativo. Todos sabemos que ao Poder Judiciário falece competência para julgar da conveniência, da extensão 
e dos efeitos políticos da intervenção. A ele compete apenas analisar a legalidade do ato de intervenção, isto é, se o mesmo está conforme alei.

Por outro lado, ninguém pode ter em dúvida a competência do Governador para decretar intervenção nos municípios e nomear-lhes interventor, desde que ocorram os pressupostos legais previstos pela Constituição Federal no seu art. 15, Constituição Estadual art. 113, § 1 . , e seguintes em harmonia com o art. 105 seus parágrafos e incisos da Lei Orgânica dos Municípios. No caso dos autos, houve uma concorrência uniforme desses requisitos legais.

A renúncia do Prefeito atingido pelo ato governamental de intervenção e que deu acesso ao Vice-Prefeito, não pode prosperar, uma vez que a medida é dirigida claramente ao Executivo Municipal e não simplesmente ao respectivo Prefeito. Se tal não ocorresse, isto é, se o Vice-Prefeito pudesse substituir em tais circunstâncias o Prefeito afastado, nulo e mesmo imprestável ficaria o instituto da intervenção, assegurado pela Carta Magna. Entretanto, a Constituição Estadual e a Lei Orgânica dos Municípios dizem expressamente que, decretada a intervenção no Município, o Prefeito afastado será substituido por um interventor nomeado pelo Governador. Releva destacar ainda que, quando o Vice-Prefeito ora impetrante assumiu o cargo, o Município de Taperoá já estava sob intervenção do Estado e com um interventor nomeado.

Veja-se a respeito o que publica o Diário Oficial do Estado de $22 / 10 / 1980$ e que circulou pela manhã daquele dia trazendo na íntegra o decreto de intervenção, enquanto que o Vice-Prefeito somente assumiu o cargo de Prefeito às 16 horas daquela dia, o que lhe era defeso fazer, estando como estava o Município sob o regime de intervenção. Claro, que dentro de tais circunstâncias o ato impugnado nenhum gravame causou ao direito subjetivo do impetrante, inocorrendo por isso mesmo, em seu favor direito líquido e certo a ser protegido pelo Mandado de Segurança.

Em nada pode aproveitar ao impetrante o argumento de que a renúncia do titular tornou sem objeto o decreto de intervenção, devolvendo-lhe o direito pleno ao exercício do cargo como seu legítimo sucessor. Isto porque, como se disse, o Município já estava sob o regime jurídico da intervenção, quando da sua assunção ao cargo e mesmo que não estivesse, restaria ainda o argumento sustentado que a intervenção se dirige especificamente contra o Executivo Municipal e não exclusivamente contra seu Prefeito.

Não vale argumentar o aspecto tido como ato violador da soberania popular, uma vez que pelo Mandado de Segurança não se defende direito da coletividade, mas tão somente o direito subjetivo do impetrante. Seria também mergulhar em seara fora do alcance do Poder Judiciário ao qual refoge o direito de examinar a conveniência e os efeitos políticos do ato governamental de intervenção.

ISTOPOSTO:

3. Acorda o Egrégio Tribunal Pleno do Estado da Paraíba, por maioria contra os votos dos Desembargadores Francisco Espínola, 
Aurélio Albuquerque e Mário Moreno denegar a Segurança impetrada por Manoel de Farias Souza Filho, cessando em conseqüência os efeitos da liminar a ele concedida." (fls. 76/79). mo:

Recorreu o impetrante, pelas alíneas a e $d$, alegando, em resu-

"... que o douto julgado recorrido negou aplicação aos parágrafos $3^{\circ}, 13^{\circ}$ e $21^{\circ}$, do artigo 153 da Constituição Federal, bem assim aos arts. 1․ § § 1. e 154, parágrafo único da Lei Magna, além de agredir os dispositivos vigentes do Código Eleitoral, lei federal, e negar vigência aos arts. 10 11 e 312 do Decreto-lei federal 2.848 de 7 de dezembro de 1940, Código Penal em vigor, e ainda ao que dispõe o Decreto-lei 201 de 27 de fevereiro de 1967 , como se verá a seguir, nas razões do presente recurso, que pede seja deferido, ex vi legis, pelo que, com a devida vênia, passa a fundamentá-lo." (fl. 82).

Negado seguimento ao recurso, determinei fosse ele processado, para melhor exame.

Opina a Procuradoria-Geral da República, em parecer da Procuradora Cecília de Cerqueira Leite Zarur, aprovado pelo Subprocurador-Geral Mauro Leite Soares:

4. Parece-nos de início inadmíssivel que o decreto de intervenção se referindo especificamente a atos de corrupção do Prefeito José Vilar fosse publicado após a renúncia do mesmo e sobretudo mantido, embora já se encontrasse legalmente investido o Vice-Prefeito, sobre o qual nenhuma acusação pesava.

5. Resulta que o ato em questão passou a atingir quem, segundo se depreende dos autos, não praticou o crime, afrontando o artigo 11, do Código Penal.

6. Conforme opinou o eminente Ministro Antonio Neder na Suspensão de Segurança 115-9, versando a matéria sub judice:

Se o decreto de intervenção atribui, expressis verbis, a José Vilar, ex-Prefeito, a conduta criminosa motivadora do ato interventivo, e se, por força do nosso Código Penal, a responsabilidade pelo resultado criminoso não passa da pessoa de quem lhe deu causa, necessária é a conclusão de que a renúncia de José Vilar ao cargo de Prefeito de Taperoá prejudicou a intervenção, por que esta, pelo fundamento único invocado no decreto impugnado (corrupção praticada por José Vilar), não pode alcançar o novo Prefeito a quem não se refere o ato interventivo sequer como participante daquela causa invocada no decreto agora discutido (fls. 114/115).

7. Ex positis, somos pelo conhecimento do apelo." (fl. 130). Éo relatório.

Senhor Ministro Leitão de Abreu (Relator) - No regime 
constitucional vigente, o município goza de autonomia. Define a Carta Federal em que consiste essa autonomia, enumerando as prerrogativas que a garantem. A mesma cláusula, que assegura a autonomia municipal (art. 15 da Constituição Federal), estatui, porém, limites a essa prerrogativa, entre os quais os derivados da intervenção do Estado no Município. Os casos em que se autoriza essa medida excepcional são arrolados nas alíneas a a $f$ do $\S 3^{\circ}{ }^{\circ}$, do art. 15 da Carta Política da União. Em todos esses casos, a intervenção, que deve ser regulada na Constituição do Estado, se opera no município, estando a sua legitimidade condicionada à existência dos pressupostos de fatos indicados pela Constituição. Verificado um desses pressupostos, cabe ao Chefe do Executivo Estadual, não apenas o poder, mas o dever de intervir no município, observados os requisitos estatuídos na Constituição do Estado, estabelecendo no decreto interventivo as medidas que entender oportunas e convenientes para corrigir as irregularidades, que hajam determinado a decisão interventiva.

A intervenção, pela qual se intenta restaurar a regularidade na administração municipal, supõe o interventor e o afastamento, por isso mesmo, do Prefeito do Município, bem que esse afastamento possua, em regra, caráter provisório, uma vez que a intervenção não é forma de destituição de cargo político, a qual só poderá ocorrer em face de outra causa legal. Em outras palavras, o ato de intervenção, ato político-administrativo, implica o afastamento de quem se ache na Chefia da Prefeitura, cujas atribuições passam ao interventor. $\mathrm{O}$ afastamento do titular da Prefeitura, pelo ato da intervenção, não importa, de outro lado, a imposição de pena ao Prefeito, mas simples medida de caráter político-administrativo, indispensável ao cumprimento dos objetivos da intervenção.

No caso vertente, a intervenção se fundou na "prática de atos de corrupção na administração municipal de Taperoá pelo Prefeito José Vilar, apurada e comprovada através de inspeção realizada pelo Tribunal de Contas do Estado" (fl. 19). Está esse pressuposto de fato - a prática de atos de corrupção na administração municipal - entre os que autorizam a intervenção nos Municípios (art. 15, § $3^{\circ}$., alínea $e$, da Constituição Federal). "Ato de corrupção" - escreve Hely Lopes Meirelles - "é todo aquele que atenta contra a probidade da Administração Pública, e, no caso, contra a administração do Município. 0 conceito de corrupção, para fins de intervenção do Estado no Municipio é mais amplo que o de crime de corrupção definido no Código Penal (art. 317). A corrupção administrativa" - prossegue - "pode assumir as mais variadas formas, praticadas às escâncaras ou dissimulada em atos e contratos legítimos na forma, mas ilegítimos no conteúdo ou na finalidade. Toda essa gama de corrupção na Aministração autoriza a intervenção no Município, para fazê-la cessar com o afastamento das autoridades e servidores corruptos ou corruptores, entregando-os à Justiça para a sanção penal cabível, dependente das sanções político-administrativas por enriquecimento ilícito, em prejuízo da Fazenda Pública". (Direito Municipal Brasileiro, Revista dos Tribunais, 3. ${ }^{a}$ ed., pág. 135).

Argumenta-se que a intervenção se estribou em atos de corrupção atribuídos ao Prefeito titular, de sorte que, afastado este, em vir- 
tude de renúncia verificada na véspera do ato de intervenção, ilegítima foi esta, porque perdera o objeto. Cumpre se tenha em conta, no entanto, que a intervenção, no caso de irregularidade na administração municipal, se opera no Município, objetivando restaurar aí a regularidade que se quebrou. Conquanto, na espécie, tais atos hajam sido imputados ao Prefeito, isso não significa que seja ele o único responsável pelas anormalidades apuradas. O normal é, pelo contrário, que, se irregularidades houve, nestas se encontrarão comprometidos, além do Chefe do Executivo, outros integrantes da administração, visto como, sem o seu concurso, dificilmente se poderiam corporificar os atos de gestão que se inquinam de ilegítimos. Requisito, no caso vertente, para a intervenção era a prática de atos de corrupção na administração municipal. Verificado esse requisito, estava intitulado o Governador do Estado a praticar o ato interventivo e a nomear , para, como seu delegado, restabelecer a ordem na administração municipal, o interventor. Pouco importa que, ante a iminência da intervenção, o Prefeito haja renunciado, pois com isso não se apagavam os atos de corrupção praticados na administração municipal, nem, por conseqüência, as irregularidades a que se reportava o Governador, nem desaparecia, necessariamente, a necessidade de providenciarse, mediante a intervenção, a restauração da normalidade nos quadros administrativos do Município.

Não havendo, diante disso, obstáculo jurídico à intervenção, não assistia direito ao recorrente, Vice-Prefeito que assumiu o cargo ante a renúncia do Prefeito, a ser mantido nesse cargo.

Como o recurso tem como fundamento a ilegitimidade da intervenção e a falta de poder jurídico do Governador do Estado para nomear interventor, já que o antigo Prefeito renunciara, argüições, no caso, de todo improcedentes, não ofendeu a qualquer norma jurídica, constitucional ou legal, o acórdão que denegou a Segurança impetrada pelo recorrente, para ver-se mantido no cargo de Prefeito de
Taperoá.

Diante do exposto, não conheço, preliminarmente, do recurso.

\section{Voto}

O Senhor Ministro Cordeiro Guerra - Não há dúvida que a intervenção foi decretada fundadamente, com apoio da Assembléia Legislativa, alicerçada em decisão do Tribunal de Contas.

Decretada a intervenção, validamente, compete ao Governador nomear o interventor.

É o que dispõem o art. 15, § $3^{\circ}$, da Constituição Federal, e, e o art. 113, IV,$\S 1$ : a, be $c$, da Constituição do Estado da Paraíba.

Decretada a intervenção, nomeado o interventor, este é da livre escolha do governador.

Afasta, portanto, o texto da Lei Maior, a ordem de sucessão municipal, deixa ao exclusivo critério do governador a nomeação do interventor, e nada impediria a nomeação do vice-prefeito, ou do Pre- 
Desejasse a Constituição preservar a ordem de sucessão do Prefeito, e não ensejaria ao Governador a escolha de um interventor.

Assim, penso que a própria Constituição Estadual, por força do disposto na Constituição Federal, afastou a ordem de sucessão normal do executivo municipal, em caso de intervenção justificada no Município.

Acresce a isso, que decretada a intervenção, nomeado o interventor na forma constitucional, nenhum efeito poderia ter a renúncia feita para evitá-la ou elidi-la.

Somente, após, completada a intervenção, o substituto legal do Prefeito poderá assumir o cargo se não se verificar, também, incompatível com o exercício das funções de Chefe do Executivo Municipal.

Penso que a renúncia do Prefeito, afastado pela intervenção válida, não a anula, ainda que a antecedesse, pois a intervenção visa regularizar a administração municipal, mediante interventor nomeado nả forma da Constituição, e não pela substituição eventual do Prefeito, pelo vice-prefeito.

Se assim desejasse, a Constituição não facultaria ao Governador a escolha do interventor.

Por esses motivos, e em que pese aos argumentos do eminente Ministro Antônio Neder, preliminarmente, não conheço do recurso.

\section{Voto preliminar}

O Sr. Ministro Djaci Falcão (Presidente): - Também acompanho o eminente Relator. Em primeiro lugar, pela consideração dos limites impostos pela Constituição ao conhecimento do próprio recurso extraordinário. Em segundo lugar, pela consideração de que a intervenção não tem um caráter penal, pois situa-se como medida de caráter político-constitucional.

A intervenção, além disso, não afronta a autonomia municipal, porque se opera por força de uma norma da lei maior - art. $15, \S 3$. da Constituição Federal - , e com isso se dá não o afastamento definitivo do titular, ou seja, do prefeito, mas um afastamento de natureza provisória, podendo ele, afinal, retornar ao cargo, após a apuração dos fatos apontados como ocorrentes na municipalidade. É em resguardo disso que existe o instituto da intervenção.

Diante destas resumidas considerações, e à vista do que expôs o eminente Relator, também não vejo ofensa a preceito de natureza constitucional, e, muito menos, a preceitos de lei ordinária.

Não conheço do recurso.

\section{Extrato de ata}

RE. 94.252-1 - PB - Rel., Min. Leitão de Abreu. Recte: Manoel de Farias Souza Filho (Adv.: Hilton Moreno Marinho, José Paulo Sepulveda Pertence). Recdo.: Estado da Paraíba (Adv.: Pedro Adelson Guedes dos Santos, José Guilherme Villela). 
Decisão: Não conhecido. Unânime. Falou, pelo Recte.: Dr. José Paulo Sepulveda Pertence. Falou, pelo Recdo: Dr. José Guilherme Villela. 2. Turma, 09/06/81.

Presidência do Senhor Ministro Djaci Falcão. Presentes à sessão os Senhores Ministros Leitão de Abreu, Cordeiro Guerra, Moreira Alves e Decio Miranda.

Subprocurador-Geral da República, Dr. Mauro Leite Soares.

(a) Hélio Francisco Marques

Secretário da Segunda Turma 